\title{
Forum
}

\section{The Role of Popular Muslim Movements in the Indian Freedom Struggle}

\section{Altaf Fatima}

We all know the old adage that "history belongs to the victors." In the case of Muslim India, this is reflected in the historical accounts of Muslim South Asia's decline during the eighteenth century and its final defeat in 1857. Written mainly by European and Hindu historians who often had no contacts beyond the Mughal court's outer fringes, they could hardly be expected to present the Muslim interpretation of events. Closer to our own time, the success of M. K. Gandhi's (1869-1948) non-violent mass movement, which finally forced the British out of India, has overshadowed earlier Muslim efforts to obtain the same goal. In this article, a glimpse is offered into this often ignored history in order to remind people that Gandhi's movement did not arise in a vacuum, but rather in a particular historical context in which Muslims had played a prominent role.

\section{Ground Realities}

The death of Emperor Aurangzeb Alamgir (1618-1707; r. 1658-1707) ushered in a period of destabilization characterized by wars of succession among his descendants and incessant attacks by the Marahata and Sikh forces. The political situation and heartbreaking accounts of military and other losses helped to create an air of defeatism. As a result, Muslim South Asians lost their will to live as self-respecting citizens, gave up their dynamism and urge to learn and advance, and actually severed their relationship with learning. Thus they lost their own history, a discipline that owed much of its development to Muslims, and became dependent upon others to tell their story. Unfortunately, these "others" have never been fair in their accounts.

Altaf Fatima, a Pakistani novelist, author, and broadcaster, retired as a professor of Urdu who specialized in the thought of Allama Iqbal. This article was translated and edited by Omar Bin Abdullah, editor of Islamic Horizons. 
For example, nothing could be further from the truth than the European and Hindu accounts alleging that Islam was spread in South Asia by the sword after the Muslim invasion. In fact, the Muslims brought learning and a new manifesto that attracted the disenfranchised masses without coercion. Poet-philosopher Allama Muhammad Iqbal (1877-1938) encapsulates this era in the following couplet:

huay iss shan say jadah paymah ihrare millat

keh hain tamashaee shigafay darr say sadiyiuoun kay zindani.

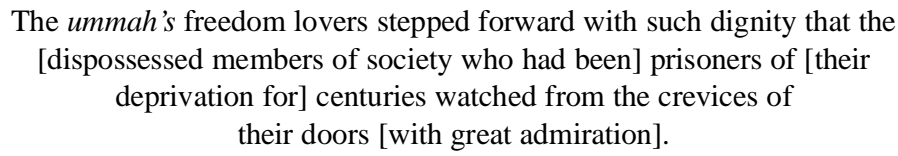

Those who invited the Indians to Islam were not soldiers, but the religious scholars, saintly personalities who served God through learning and piety, dervishes, and members of Sufi orders who accompanied the soldiers and settled down to teach and instruct. No ruler guided or paid them, for such undertakings were volunteer efforts to share the message of Islam. Inspired by a desire to share Islam, which offered liberty and equality to all people, they attracted many local people. There were many instances of one branch of the family entering Islam while the other continued in its traditional faith. India's first Muslim emperor, Zahir-ud-din Mohammad Babur (1483-1530; r. 1526-30) states in his autobiography, Tuzuk-e Babari, that the aims of his conquest did not include forced conversions to Islam. As neither the Mughals nor the earlier Muslim rulers forced their beliefs on the local populace, the majority of the people retained their traditional beliefs and their places of worship remained safe and secure.

Islam spread because of the teachings imparted by its scholars and spiritual leaders. In fact, under the Mughals, Delhi used to be called the baees khwaja ki chawkhat (the doorstep of twenty-two scholarly giants). But its rapid spread created its own challenges, among them providing the necessary training and education to maintain such a pace. At first, these sages trained and entrusted their successors and murids (scholar-disciples) to meet this need and asked them to nurture their own assistant scholar-representatives. However, this system could not prevent the emergence of a great uneducated and semi-literate new Muslim population that kept many of its un-Islamic local customs and practices. Over time, the followers of a religion that taught action and advancement fell prey to alien ways and customs, a development that led to the Mughal Empire's weakening and destabilization. 
While this was going on, the European powers, especially the French, the British, and the Portuguese who had come to India for trade, started warring among themselves for control. It was at this time that the British East India Company's (hereinafter "Company") officers correctly assessed that the Marahatas and Sikhs had weakened the Mughal Empire and that the Company would benefit by finishing it off. In addition, such a victory would help them overpower the French and Portuguese and turn India into a British fiefdom. This plan came to fruition in 1857, when the Red Fort fell to the British and they arrested the last Mughal ruler, Bahadur Shah Zafar (17751862; r. 1838-57). Finally, the largest hurdle to Britain's direct rule of India, namely, the Muslims, was removed and ruling through surrogates became unnecessary.

However, this scenario was far from being the walkover as some British and Company officials had imagined. British historians mislabeled India's 1857 war of independence as a "mutiny," and although Queen Victoria assumed the title "Empress of India" in 1877, the anti-British struggle continued. The British pretense of subordination to the emperor in Delhi was abandoned, his name was removed from all coinage in $1835 .{ }^{1}$ Two years later, Persian was abandoned as the language of record and the courts and replaced by English and regional languages, a decision welcomed by the Anglicized Bengali Hindus. Muslims deplored it, however, and their numbers in the administration steadily declined. Consequently, British officials, now trained initially in England and increasingly accompanied by their wives, became socially and intellectually more aloof from their Indian subjects.

\section{The Faraizi and Other Freedom Struggles}

Jamal Malik of the University of Erfurt, Germany, notes:

For a long time, the Indian revolt of 1857 was known as the "Sepoy Mutiny." This of course was from the perspective of colonial historiography, which later was challenged by nationalist historians of various camps, who considered this event as a marker of the first war of independence. ${ }^{2}$

The question arises of how the totally demoralized and receding Muslims were able to rise up against their colonial overlords. Throughout their history, whenever the ummah has reached a low point some reformers always emerge. This period saw the rise of several low-key reformist efforts, the earliest of which was Haji Shariat-ullah's (1781-1840) launching of nineteenthcentury Bengal's first Islamic reformist movement. Although not a geographically widespread movement, its effects were felt across the Subcontinent. 
Born in Bahadarpur village (Faridpur district) to an observant Muslim family, Shariat-ullah performed hajj as a youth and ended up staying in Makkah from 1799-1818 to pursue higher Islamic education. Upon his return home in 1820, he launched the Faraizi (obligationist) movement, a non-political effort undetaken to educate the people about the Shari ah and help the Muslims shed the local customs and superstitions that had, over the years, entered Islam. In their early years, reform movements usually meet with resistance; however, Shariat-ullah's simple and honest ways won over many people. He went on to found a school that offered education and encouragement during a time of despondency. Soon other potential reformers began to seek his advice and guidance. In turn, his son Muhammad Mohsin, popularly known as Dadhu Mian (b. 1819) and who also performed hajj during his youth, continued his father's mission.

The young man was proficient both in his father's teachings and in organizational matters. When he saw that the workers needed both education and economic help, he launched an agricultural development movement. As a result, the Faraizi movement soon became a religio-economic movement. While peasants across the Subcontinent were suffering, the situation of the Bengali Muslim peasants and artisans was the worst, for they were hemmed in on one side by the Muslims' overall backwardness and on the other by the spiteful activities of their rich and powerful Hindu landlords. The movement encouraged peasants and tenant farmers to obtain signed leases from their landlords to help establish their occupancy rights. The landlords, however, refused and even sought to levy an additional charge upon their tenants. Dadhu Mian, repeatedly jailed by the British, always stood by the poor peasants and tried to provide succor and support and even their legal defense. The Faraizis "succeeded in redefining Islamic belief and practice among the many Muslim peasants in eastern Bengal" and also the "sense of communal identity, of being a Muslim, was clarified and made explicit."”

Long before the Faraizi movement, the eighteenth century saw the rise of the comprehensive movement led by Shah Waliullah Muhaddith Dehlavi (given name: Qutubuddin Ahmad; 1703-62). The Walilullah movement arose at a time when Muslims were reeling under the effects of the Iranian ruler Nadir Shah's 1739 invasion and subsequent sack of Delhi, which had left thousands dead and millions lost in assets. The devastation was such that some Muslims followed the Hindu Rajput tradition of committing suicide by burning one's self, family, and possessions after defeat in battle. Although Waliullah's movement cannot be identified as a direct action to expel the British colonialists, it sought to end the Muslims' despondency and enthuse them with a new spirit and mindset. 
Before launching his movement, Walilullah studied and analyzed the challenges facing his people. He found that the Muslims' economic and political backwardness was rooted in the deterioration of their social system due to the absence of enlightenment and the infusion of alien ways into a simple and straightforward faith. He had two core beliefs: (1) the Muslim community could not be emancipated without replacing the existing exploitative and unjust system with a just and equitable order, and (2) that an organized party could undo the outdated order and prepare itself to wage a struggle for freedom, even an armed one, if needed.

Thus, his first priority was to rejuvenate the social structure that had been undermined by the loss of moral values and the pursuit of self-interest. His approach was to address all sections of the community, beginning with the ruling class. However, after meeting no success among the ruling elite, he tuned toward the rich and powerful. After being disappointed by the rulers in Delhi and Deccan, Walilullah approached Najib ud-Daulah (d. 1748), the ruler of Rohilkhand, to contact Ahmad Shah [Durrani] Abdali (1723-73), the ruler of Afghanistan, whom he implored to fulfill his obligation as a Muslim ruler and defend India's Muslims against the Sikh and Marahata onslaught. Abdali asked Najib to create a united front of the independent Muslim states in northern India and Central Asia. Najib succeeded in this undertaking, and these forces joined with Abdali's forces to defeat the Marahata Confederacy at Panipat (1761). Although this was not a lasting triumph, it provided a much needed period of relief from Hindu and Sikh oppression.

During this time of relative peace, Waliullah reached out to his movement's two important players, namely, the peasants and artisans who formed the two pillars of that era's economy. He also continued his efforts to uplift all social sectors, both spiritually and morally. The cornerstone of his movement was the belief that freedom and prosperity could be attained only by creating a just society.

Although Waliullah did not succeed in his mission, he nevertheless offered a revolutionary model that could be emulated and encouraged Muslims to seek higher goals. More importantly, through his writings and speeches he helped create thinkers and scholars who would leave their lasting marks on the nation's future. In addition, his son Shah Abdul Aziz Muhaddith Dehlawi (1745-1822) not only continued his father's mission, but also authored Fatah al-Aziz, which explained in easily understandable language the Fatah al Rahman, the first commentary on the Qur'an that his illustrious father had penned. Abdul Aziz was fully involved in helping Indian Muslims improve their situation. After the Company established its writ and 
people became disenchanted with the Mughal rulers, Abul Aziz issued a fatwa declaring that it was irrelevant whether the British were or were not interfering with the performance of Islamic rites, for since Muslims had lost control of the government India had become a war zone (dar al-harb). Thus, all Muslims were obliged to engage in jihad against the occupation. This was the first call to arms against the Company's hegemony.

This call came at time when Emperor Shah Alam II (1728-1806; r. 17611805) had become a stipend-holder of the Company and the saying "King Shah Alam [lit.: monarch of the world] just rules from Delhi to Palam" (scarcely ten miles southwest of old Delhi) had become widespread. In such an atmosphere of defeatism and despair, it was a monumental task to organize any movement or call among Muslims for change. In such a setting, this fatwa's impact could be likened to a pebble falling into a stagnant pool of water; it had no immediate impact. However, it became the first and strongly pronounced declaration for India's freedom and, over time, would give birth to a movement that sought to lay the foundation of a government that drew inspiration from the word of God. The truth is that the various nineteenth-century Muslim movements for emancipation were branches of this noble tree, such as the early nineteenth-century Faraizi movement.

Waliullah's revivalist movement, nurtured by his son Abdul Aziz and continued by Sayyid Ahmad Barelvi (1786-1831) - the Tariqah-i-Muhammadiyah movement - and [Shah] Sayyid Muhammad Ismail Shaheed (1779-1831), found another proponent in Sayyid Ahmad [ibn Irfan] Shaheed (b. 1786). His maternal grandfather Sayyid Abu Sa`eed al-Hasani, was among Waliullah's students. Indeed, Sayyid Ahmad Shaheed's movement reflected the true essence and character of Waliullah's and Abdul Aziz's thought. He also drew inspiration from the Faraizi movement and Titu Mir's movement. Thus, he combined the essence of these three movements and crafted a plan for his own time and challenges. Similarly, he sought to reform the Muslim community on the grounds that social and spiritual reconstruction was central to its progress and development. He maintained that the nation could be trained for a higher calling only after it had shed its syncretistic practices.

In 1819, on the advice of his teacher Abdul Aziz, this inspiring speaker set out for Makkah, sailing from Calcutta in twenty boats carrying 800 of his friends and followers. Arriving in Makkah in 1820, he met with and exchanged ideas with Bulgarian and Egyptian scholars. Upon his return, this energized, reinvigorated, and more knowledgeable man prepared for jihad. In the meantime, a new enemy had arisen, namely, the Sikhs, who now ruled the Punjab with Britain's blessings and support. As a result, the 
Sikhs had launched a reign of terror and had even banned calling the adhan in mosques. Therefore, it was necessary to fight them first and then the British.

The British sought to counter Sayyid Ahmad Shaheed by pitting Muslim against Muslim. A vicious whispering campaign, accusing him of being a "Wahhabi" because he forbade worshipping at graves and obedience to saints, was started. Despite such machinations, however, he continued his campaign against the Sikhs. His fighters became a major irritant to Maharaja Ranjit Singh (1780-1839), who was obliged to sue for peace. However, Sayyid Ahmad Shaheed could not accept the terms offered. As his followers advanced to Peshawar, he joined them and, in 1830, took over the city and launched his drive for social and moral rejuvenation. Among his reforms was ending the custom whereby the bride was withheld from the groom until he could pay a certain sum of money. This could take years. He also shut down liquor stores, gambling dens, and houses of prostitution and appointed Maulvi Syed Muzaffar Ali as the city's judge. After setting up the administration Sayyid Ahmad Shaheed advanced toward Balakot, where he was martyred on 6 May 1831. His death was a source of satisfaction for the Sikhs and the British.

Sayyid Ahmad Shaheed's martyrdom could be called a setback to his forces. However, he had launched his mission being fully aware of such a possibility. His sole objective was not a quick victory or an overnight revolution, but to create an awareness among Muslims about the need to stand up against injustice and oppression and to cleanse Muslim society of its acquired superstitions and customs.

Iqbal eulogized such sacrifices in Farsi:

Saray khakay Shaheeday laala haayay khoon may paasham Ki khoonash baa nihaalay millatay maa saazgaar aamad

I am rubbing the bloodied tulip on the grave of a martyr, because I believe that [the power of] their blood is conducive to our ummah's growth.

And in Urdu:

Sila shahhed kiya hai, tabb o tabb e javedaana

What is the martyr's reward but an everlasting, ever-rewarding existence?

This great freedom fighter's martyrdom inspired generations. His struggle was not merely an emotional reaction to occupation and oppression, but 
rather a well-planned and well-directed mission that drew followers from across the Subcontinent. There was no desire for wealth or power, but only the determination to undo the injustice and oppression being perpetrated by the British and the Sikhs against the Muslims of western and northwestern India and to reconstruct Islamic thought.

The Sikhs celebrated his martyrdom by setting Balakot ablaze. Only 300 children among his followers survived the fire; they returned to Tounk with his widow. About 150 of his able-bodied followers, however, moved to Sathiana, which soon became a center of their freedom struggle. Their movement was so well-organized that donations and volunteers continued to pour in from all parts of India, especially from Bengal and Bihar. In fact, the Sathiana movement became so strong that it sent a contingent to fight alongside the Afghans during the 1839-41 British invasion of that country. Unfortunately, the British overran the Afghan forces and dynamited Ghazni's gates; among the dead were over 300 members of the Sathiana contingent.

\section{The Mughal Empire Falls}

This campaign laid the foundations of the war of independence that would break out in 1857. Although there was an apparent silence during those years, the embers of freedom did not die. The campaign started with a mysterious distribution of chapati, an eternal Indian culinary favorite, and roses. Still buoyed by their success against the Muslim freedom fighters, the British Residents (government representatives) noted that these two items were being passed along, but did not attach much importance to this despite sensing possible trouble. In fact, these items were a symbol of national unity; their mere passage from one end of India to the other was an indication of widespread coordination among the people. A visitor bearing a chapati and a rose would knock on a door, the resident would take a small piece of it and smell the rose, and quickly prepare a fresh one for the visitor.

The British officers were receiving intelligence about this campaign, especially in Bengal. As harmless as it might look, the freckled brown, round chapati caused fear and loathing among them in 1857. J. W. Sherar wrote that if the objective behind the strategy (chapati running) was to create an atmosphere of restlessness, the experiment had been successful. ${ }^{4}$ In his "Host of Midian: The Chapati Circulation and the Indian Revolt of 185758," 5 Troy Downs of the University of Southern Queensland, Australia, notes that reports claiming that the chapati distribution was expanding at a geometrical rate simply reflected the British colonialists' astonishment at the speed at which it was being passed between villages, a speed that seemed to 
exceed that at which their own government orders were transmitted. Downs explains further that "the speed of the chapati movement contributed to its mystery and drew attention to the seemingly independent and uncontrollable nature of the event."

British officials also noted that groups of religious scholars were traveling to Delhi and reminding worshippers at the Jamia Masjid's Friday prayers that India had become part of the dar al-harb, since it was now occupied by Britain, and that these visitors would vanish after giving some lectures. Among such visitors was Molana Fazle Haq Khairabadi, the son of Molana Fazle Imam Khairabadi.

The battles of Plassey (1757), Mysore (1799), and Sarangapatam (1799) resulted in martyrdom for Mirza Mohammad Sirajud Dawla, more popularly known as Siraj ud-Daulah (1733-57), the Nawab of Bengal, Bihar, and Orissa, as well as for Sultan Fateh Ali Tippu, more popularly known as Tipu Sultan and the "Tiger of Mysore" (1750-99). But the standard of freedom that they had hoisted remained unfurled even after their departure. Some nine years after Tipu's martyrdom, General Bakht Khan Rohilla (17971859) took up this standard. At that time, Mughal influence did not extend beyond the Red Fort, where seventy-five-year-old Bahadur Shah Zafar, the last Mughal ruler, existed on a grant from the Company. Forbidden to name his successor, Sir Charles Metcalf, the British Resident of Delhi, worked to create ill-will among Zafar and his sons. The most influential persons who enjoyed his full confidence were Queen Zeenat Mahal and Mirza Ilahi Baksh, the father-in-law of Zafar's son Mirza Fakhruddin. The tragedy was that Ilahi Baksh was secretly collaborating with the British. He had opposed the proclamation of jihad issued against the British and, through secret correspondence, assured them of his full support. A letter from a British spy, dated 4 August 1857, revealed that Ilahi Baksh had won over to the British side such important figures as Queen Zeenat, Hakeem Ahsanullah, Mukhund Chund, and Mufti Sadruddin, all of whom were close to the emperor. ${ }^{7}$

When General Bakht Khan raised the banner of freedom, the Muslims were totally disorganized and disheartened. However, he found followers among the religious scholars who had been inspired by Waliullah's and Sayyid Ahmad Shaheed's movements, as well as among some of remnants of the Balakot contingent who were still resisting the British. The general's campaign received a boost from the fatwa signed by Chief Mufti of Delhi Sadruddin Khan Azardah, Molvi Abdul Qadir, Qazi Faizullah Delhavi, Molana Faiz Ahmad Badiouni, Dr. Molvi Wazir Khan Akbar, Syed Mubarak Shah Rampuri, Molvi Fazle Haq Khairabadi, and other scholars. In fact, 
Molvi Fazle Haq Khairabadi had drafted this fatwa after meeting with the general, presented it to the people at a Friday prayer, and then persuaded the other scholars to endorse it.

Malik writes that Khairabadi not only issued a fatwa-e jihad against the British, but also drafted what would have been the first constitution of liberated India. Malik adds that besides being a scholar of Islamic studies and theology, Khairabadi was also a literary personage, especially in Arabic literature. On account of his deep knowledge and erudition, he was called allama and, later on, was venerated as a great Sufi. Although he was not a marginal character in the history of 1857 , yet somehow his presence has been undermined, if not totally ignored, by mainstream historians. Malik notes:

Though Khairabadi remains alive in Urdu and Persian literature, we hardly find vernacular voices being heard in historical accounts that are important to ascertain the nature of the 1857 revolt [sic]."

After the failure of the 1857 war of independence, several Muslim spies for the British helped bring many freedom fighters to trial, several of whom were found guilty and hanged until they were dead. Mufti Sadruddin Azarda, Nawab Mustafa Khan Shaifta, and poet Mirza Asadullah Khan Ghalib were all tried, while Khairabadi was declared a traitor. While Azarda, Shaifta, and Ghalib won hard-fought reprieves, Khairabadi, who was arrested for drafting the fatwa-e jihad and inciting revolt, was brought from Sitapur to Lucknow. He chose to represent himself. During the trial, a government collaborator and witness turned hostile and said under oath that this was not the same Khairabadi who had authored and signed the fatwa. One member of the jury was also not disposed to convict Khairabadi.

However, Khairabadi could not accept the witness' lies and declared that the government collaborator had filed a true report that it was he, Khairabadi, who had drafted and facilitated the fatwa. Perhaps the collaborator had had a change of heart after facing him in court, but the truth, Khairabadi said, is that he had not changed one inch from the stand he had taken in his fatwa. The astounded judge tried to intervene, but Khairabadi insisted that he was true to his opposition of the British occupation. ${ }^{9}$ Thus, in 1859 Khairabadi was sentenced to imprisonment with hard labor in the Andaman Island penal colony.

It was here that a literature-loving British jail official, who also happened to be a student of eastern knowledge and languages and astronomy, soon discovered that one his charges was also a student of mathematics and astron- 
omy. This official, unable to do the work assigned by the British officer, requested Khairabadi to review this treatise on astronomy written in Farsi. Within a few days, Khairabadi not only edited the language but also provided him with many references and suggestions for improving his thesis. When the officer asked the official where he could obtain the books he had referenced, the latter told him that Khairabadi, not he, had edited the paper. The officer sent for Khairabadi, who entered his office still carrying the straw basket used by the prisoners to carry construction material. The officer not only changed Khairabadi's designation to office clerk, but also recommended that his sentence be commuted. Family and friends had also been seeking his freedom. However, when the order of his release arrived, Khairabadi had already breathed his last on 2 Safar 1287 (1861) and was buried on the island. This closed a chapter of the religious scholars' struggle originally launched by Walilullah.

A salient feature of this movement was that the torch of freedom was passed forward through generations of scholars, leading to the war of independence in 1857, during which the passive and weak final Mughal ruler, Bahadur Shah Zafar, was obliged to collaborate with General Bakht Khan. In addition, Zafar ordered all of his sons, except for Mirza Mughal (1817-57), who had surrendered to the British, to fight under the general's leadership. Their movement gave hope to a sinking ruler. Even when he was defeated and forced to seek refuge in Emperor Humayun's mausoleum, he did not regret his decision. Upon learning that the deposed emperor had not eaten for three days, British commandant Maj. William S. R. Hodson (1821-58) sent a covered platter to him. When Zafar removed the cover, he saw the heads of his two sons and grandson, along with that of Mirza Mughal. The brave emperor did not shed a tear; rather, he sent a reply that God be praised that the sons of Taimur (1336-1405), the legendary conqueror also known to the West as Timur the Lame because of his limp, who had conquered much of western and central Asia and founded the Timurid Empire and Timurid dynasty (1370-1405) in Central Asia (which survived until 1857), had come to the father's presence with their heads raised.

The end of the jihad in May 1857, which resulted in the emperor's arrest and exile to Rangoon, Burma, cooled but did not completely douse the embers of freedom. The movement continued through Sir Syed Ahmad Khan (founder of the Aligarh movement; 1817-98), Allama Iqbal, and Mohamed Ali Jinnah (1876-1948). 


\section{Endnotes}

1. The very odd thing about this period is the ambiguity about just who owned British possessions in India and who the real sovereign authority was. Originally, British Indian coins simply said "East India Company," the chartered British company that was the ruler of British India. Since Bengal had been a possession of the Moghul Emperors, this fiction was maintained at least until 1827. The Moghul court language, Persian, was replaced by English in 1828. In 1835, the face of the King of England (William IV) began appearing on East India Company coins, but this implication of sovereignty does not seem to have been accompanied by a formal claim of sovereignty. This was not settled until 1858, when the last Moghul was deposed, the East India Company was abolished, and the Governor-General became the Viceroy, the sovereign agent for Queen Victoria. See www.friesian.com/sangoku.htm\#moghuls.

2. Jamal Malik, "The Case of Fadl-e Haqq Khairabadi in the Andaman Penal Colony," Indian Economic \& Social History Review 43, no. 1 (2006): 77-100.

3. Geraldine Forbes, et. al., The New Cambridge History of India (Cambridge University Press, 1987), 22 and 24.

4. J. W. Sherar, Life during the Indian Mutiny (London: 1910).

5. Troy Downs, "Host of Midian: The Chapati Circulation and the Indian Revolt of 1857-58," Studies in History 16, no. 1 (2000): 75-107.

6. Ibid., 81 .

7. “The Tragicomic Hero, Basharat Hussain Qizilbash,” The Nation (Lahore), 30 June 2006.

8. Malik, "The Case of Fadl-e Haqq Khairabadi."

9. William Dalrymple, The Last Mughal: The Fall of a Dynasty, Delhi, 1857 (Bloomsbury Publishing: 2006). 